\title{
ALFRED P. SMITH: BERGEN COUNTY'S LATTER-DAY BEN FRANKLIN
}

\section{BY DAVID STEVEN COHEN}

Mr. Cohen teaches history at the Newark College of Arts and Sciences, Rutgers University

I $\mathbf{N}$ a modest house on Chestnut Ridge, overlooking the Saddle River Valley, in Bergen County, New Jersey, lived a curious, little man named Alfred P. Smith. Here, during the I 880 s and I 890s, Smith published The Landscape; A Country Nerospaper. ${ }^{1}$ It was a monthly publication, consisting of four pages, only six by eight inches in size. A. P. Smith printed the paper right in his home, and he himself performed the roles of publisher, editor, and printer. Technically, The Landscape was an amateur newspaper. In one of the first issues, Smith wrote that "our paper is not intended to compete with the ordinary papers of the day. It has its own peculiar field and its own peculiar mission. It is intended as A LETTER TO OUR FRIENDS on matters of interest ...”2 But it was not a typical amateur newspaper, most of which were printed by young boys for private circulation. During its first year, A. P. Smith's paper was for private circulation only and not for sale. But by 1884 he was accepting advertisements from local merchants, and by 1887 he was selling subscriptions for fifty cents per year and advertisements for seventy-five cents a column inch. The Landscape is of special interest because A. P. Smith was black.

Alfred P. Smith was born on July 6, I 832 in Saddle River, New Jersey, in the same house in which he lived as a man. He was second oldest of five children born to Peter and Catherine Smith. His parents were members of the Zion Lutheran Church in Saddle River, where Alfred was baptized. His father was a laborer who later

1 There is no complete collection of The Landscape. Partial holdings can be found in: the Harris Collection, John Hay Library, Brown University, Providence, Rhode Island; the New Jersey Historical Society, Newark, New Jersey; the New Jersey Collection, Alexander Library, Rutgers University, New Brunswick, New Jersey; and the Pascack Historical Society, Park Ridge, New Jersey. Some early issues are reproduced in Hohn Hosey Osborn, Life in the Old Dutch Homesteads, Saddle River, N.J., from 1708 . 2d. ed. (Paramus, N.J.: Highway Printing Co., 1967). A bound volume of all the issues from June 1888 through June 1894 is kept in the borough hall, Saddle River, New Jersey.

${ }_{2}^{A}$. P. Smith's Paper (Saddle River, N.J.), December I881, p. 2. 
acquired a small farm. ${ }^{3}$ In later years A. P. Smith liked to think that the Smiths of Saddle River were related to Gerrit Smith ( I 797I 874) of Petersboro, New York, the famous philanthropist, reformer, abolitionist, and supporter of John Brown. In an issue of The Landscape, A. P. Smith claimed to be descended from Gerrit Smith's father, Peter Smith (I 768-I 837), who was born near Tappan, New York, and who for a brief time was a partner in the fur trade with John Jacob Astor. A. P. Smith believed that his grandfather, Samuel Smith, was a son of Peter Smith. ${ }^{4}$ However, the biographer of Gerrit Smith notes that Peter Smith had six children, none of whom were named Samuel. ${ }^{5}$ A. P. Smith's grandfather, Samuel Smith, married Elizabeth De Groat, who was one of the Ramapo Mountain People. They had seven sons and three daughters, of whom Alfred's father, Peter, was the oldest. ${ }^{\circ}$

A rare photograph of A. P. Smith shows him to have had a light complexion. ${ }^{7}$ Local residents of Saddle River believed that he had Indian ancestry. Perhaps this was because of the family tie to the Ramapo Mountain People, a racially mixed population who claimed Indian ancestry, but who have been shown to have definite black and Dutch ancestry. ${ }^{8}$ Smith's father and his family were listed in the I 850 manuscript federal census as white, but in subsequent censuses they were listed as either black or mulatto. ${ }^{9}$ Smith's race was recorded on his death certificate as Negro. ${ }^{10}$

Since boyhood, A. P. Smith was crippled from a disease he contracted from excessive bathing. He was educated in the public schools, and as a young man he taught school himself. Then he worked as a reporter for the Paterson Guardian. Smith never

\footnotetext{
${ }^{3}$ Records of the Zion Lutheran Churches of Saddle River and Ramapo, New Jersey, compiled by Herbert S. Ackerman and Arthur J. Goff, I 943, pp. 2, 4, 39, 40, 45, 49, 58 ; U.S. Bureau of the Census, Seventh Census of the United States: 1850 . New Jersey. (manuscript); U.S. Bureau of the Census, Eighth Census of the United States: 1860. New Jersey. (manuscript).

"Quoted in "The Jackson Whites: A Study of Racial Degeneracy" (unpublished mss., Vineland Training School, Vineland, N.J., cir. I9II), p. 88. A microfilm copy of this manuscript is located in the New Jersey Collection, Alexander Library, Rutgers University, New Brunswick, New Jersey.

${ }^{5}$ Octavius Brooks Frothingham, Gerrit Smith: A Biography (New York: G. P. Putnam's Sons, 1879), pp. 20-2I.

6 "The Jackson Whites," p. 88.

${ }^{8}$ David Steven Cohen, The Ramapo Mountain People (New Brunswick: Rutgers University Press, 1974).

${ }^{9}$ U.S. Bureau of the Census. Seventh, Eighth, Ninth, and Tenth Censuses of the United States: $1850,1860,1870$, 1880. New Jersey. (manuscript).

${ }^{10}$ Report of Death, New Jersey Department of Health, Trenton, New Jersey, Microfilm Reel I 85 , No. 2740 I.
} 
married. After his father's death in 1876 , he remained at home to take care of his elderly mother. To support himself and his mother, he bought a printing press and started a job-printing business in his home. In I $88 \mathrm{I}$ he began an amateur newspaper, originally known as $A$. P. Smith's Paper. In I 882 he changed its name to The Landscape.

The Landscape contained mostly local news, such as the scores of local baseball games and notices of births, deaths, marriages, and the travels of the residents of Saddle River. A. P. Smith's interest in science and nature was expressed in brief articles on geology, botany, and fossils. He reflected on the changing seasons with items such as: "The frozen ground, the ice and snow, the freezing wind, the naked trees and gray fields, the shivering snow-birds and blue jays, skies betokening storm, people huddling for comfort around the stove-this is Winter."11 The Landscape also printed poetry submitted by amateur poets. Miss Caroline Bacon, a retired school teacher from Worcester, Massachusetts, who signed her poems "Carrie," was a frequent contributor. Another contributor was Arthur H. Goodenough from West Brattleboro, Vermont, who in I 896 was awarded the title "Poet Laureate of the Amateur Press Association of America." Smith also reprinted anecdotes, jokes, proverbs, and excerpts from other newspapers to which he subscribed. This was the common practice of even the larger newspapers, before the establishment of the national news services. But Smith proudly refused to allow his paper to become another "Patent Outside," that is, a country newspaper whose editor for a fee is furnished by city publishers with an already printed sheet containing a blank space for local news and the banner.

Although Smith once referred to the paper as "our colored supplement," The Landscape cannot be considered a "black" newspaper. While Smith had black ancestry, most of his readers were whites. Nevertheless, A. P. Smith was outspoken on the plight of his fellow blacks. He was a great admirer of the former slave, abolitionist Frederick Douglass, whom Smith once met at a public lecture. In the obituary he printed at the time of Douglass' death, Smith described him as "one worthy to take rank with the nobliest of heroes of liberty of any age or country . . "12 He was pleased by the acclaim given to Booker T. Washington, but he was insulted by those whites

11 The Landscape (Saddle River, N.J.), December I893, p. 3.

12 Ibid., March I 895, p. 2. 
who thought Washington was remarkable because he was literate. "The South has thousands of colored men, intelligent and educated, who can make as good a speech as that of the now famous black orator of Atlanta." 13

Smith held in high regard Northern veterans of the Civil War, and he announced their reunions in his paper. He did not think that former Confederate soldiers should be given equal respect. Upset about the return to power in the South of the Democratic Party, Smith wrote: "We were not willing to surrender to the 'Solid South' on the battle-field, and we are not willing to surrender at the ballot box." ${ }^{14}$ Smith protested the terrorizing and lynching of blacks in Louisiana and Mississippi. He advised Northerners against investing money in the South.

While people are murdered or driven from their homes, mob-cursed Louisiana, Mississippi, and other banditti-ruled states are holding conventions inviting capital, etc.

"Will you walk into my parlor?"

Said the spider to the fly. ${ }^{15}$

Smith had little use for the Democratic Party. In I 892, he wrote that "our readers will hardly expect us to do much rejoicing" about the election of Grover Cleveland to his second term in the White House.

In the midst of the rejoicings we hear the wail of despair from the millions of the oppressed in the Southern states, and so far as it is a return of the rebel element to power, which regard it as a victory in favor of new oppressions and outrages, we can only contemplate it with horror. ${ }^{16}$

Smith thought that the Southerners who came North were educated people to whom the treatment of blacks in the South was repugnant, but "the millions who control the South, and thought it the whole country, are in education, manners, and morals, inferior to the inhabitants of the Ramapo Mountains."

Smith was also mindful of the condition of blacks in the North. He reminded his readers that New Jersey also had slavery at one time.

A bit of song of the "good old times" in New Jersey has come down to us from the following lines, which used to be sung by the slaves in Bergen county:

\footnotetext{
13 Ibid., October 1895, p. 2.

15 Ibid., April I 893, P. 2.

17 Ibid., March 1894, p. 2.
}

14 Ibid., July I $89^{2}$, p. 2.
16 Ibid., December I892, p. 2. 
"Cold, frosty morning,

Nigger berry good.

Wid his axe on his shoulder,

And away to the wood,

Wid a piece of cold pancake

And a little hog's fat,

And dey grumble like de debble,

If you get too much of dat."18

He chastised Englewood, New Jersey, for maintaining a segregated school system: "ENGLEWOOD enjoys the unenviable distinction of maintaining the only caste school in the county. Shame on you, Englewood!" "Englewood, attention! an Equal Rights School Law passed the last Legislature. Paterson, remember! Your Godand-mammom preacher-politician Robinson opposed it!"20

During the Boer War, Smith expressed support for Great Britain. The government of Transvaal, he wrote, "is an unmitigated tyranny and its treatment of natives and outsiders is cruelly and outrageously unjust."21

A. P. Smith did not consider The Landscape to be primarily a political organ. In I $88 \mathrm{I}$, he wrote:

At present a bitter fight is raging between Garfield and Conkling, but it will pay farmers better to pick potato bugs than to read all the papers have to say on the subject. After this, any time left may be profitably devoted to reading the New Version [of the Bible], or, if they prefer, in getting acquainted with the contents of the old one. ${ }^{22}$

But from time to time he couldn't resist the urge to express his political opinions. A. P. Smith was a Republican, but at times he did endorse Democrats. He helped defeat Republican William Walter Phelps in his campaign for the Congressional seat from the Fifth District, because Phelps opposed the civil rights bill of 1875 . He later, however, became a supporter of Phelps. In the I 895 primaries, Smith endorsed Augustus W. Cutler for the Democratic nomination for governor. He wrote that Cutler was "the only man in either party in whose success 'the plain, common people' take an interest."23 When Alexander McGill of Jersey City defeated Cutler for the nomination, Smith complained that "the old rounders and ringsters

18 Ibid., November I 888 , p. I.

${ }^{19}$ A. P. Smith's Paper (Saddle River, N.J.), June I 88 I, p. 4.

${ }^{20}$ Ibid., December 1881 , p. 4.

21 The Landscape (Saddle River, N.J.), February r9oo, p. 2.

22 A. P. Smith's Paper (Saddle River, N.J.), December I 88 I, p. 3.

${ }^{23}$ The Landscape (Saddle River, N.J.), August 1895, p. 2. 
had everything their own way ..." ${ }^{24} \mathrm{He}$ wrote an article titled "How It was Done."

The popular movement was in favor of Hon. A. W. Cutler for the Dem. nomination for Governor, when the "machine" took up McGill as its candidate. The machine, reenforced [sic] by Senator Smith, backed by the Federal patronage, of which he is sole dispenser in New Jersey, defeated the people. The Federal patronage, thus used, is what decided the result. ${ }^{25}$

Political bossism was one of Smith's pet gripes. In I 890 he supported the Australian or secret ballot reform, but he was under no illusions that it would provide a panacea. "That it will do much good we greatly doubt," he wrote. "As long as truth and justice are perverted and derided, and wrong and injustice approved and taught THE BALLOT IS CORRUPTED AT ITS SOURCE." ${ }^{26}$ Smith complained that the state legislature and "corrupt courts" were "in league with and protecting the poolcellars and gambling halls." ${ }^{27} \mathrm{He}$ favored the election of local and state judges. In 1895 he wrote: "If under the new law the people of Bergen county may have something to say in the election of Judges, instead of having the Judge selected by a ring in Hackensack, it will be a good thing." ${ }^{28}$ Smith also supported the movement in the I 890 s to break up large townships into small boroughs. But he realized that the borough system of government was no guarantee against corruption. He noted that: "Readers of English politics are familiar with the term 'rotten borough.' But England has no boroughs as 'rotten' as some of the newly formed boroughs of Bergen County.",29

A. P. Smith was an early supporter of both the temperance movement and the women's suffrage movement. In 1889 he wrote,

If the proper number of signatures can be obtained, an election under Local Option Law will be held in Bergen county. The sale of liquor by the local option of public sentiment has long been prohibited in Saddle River and Allendale-and the result gives general satisfaction. ${ }^{30}$

Of the suffragette movement, he noted in 1894: "The women of New York are asking the right of suffrage. We are heartily in favor for the very simple reason: IT IS RIGHT." "31

Smith barely made a living from his little newspaper. He wrote: "The Landscape has kind friends in Saddle River, but in a place with

\footnotetext{
24 Ibid., October 1895 , p. 2.

${ }^{26}$ Ibid., February 1890, p. 2.

28 Ibid., June I 895, p. 2.

${ }^{30}$ Ibid., January I 889, p. 2.
}

25 Ibid., November 1895, p. 2.

27 Ibid., December I893, p. 2.

${ }^{29}$ Ibid., September 1894, p. 2.

31 Ibid., May 1894, p. 2. 
a population of less than 75 families, more than half with strongly marked rural characteristics, no one will get rich publishing a newspaper." ${ }^{32}$ In the spring of I 890 he was so badly in debt that, at the sacrifice of some pride, he had to print a public appeal for forty dollars. The Englewood Press raised the money through contributions from its readers, and others responded with subscriptions and contributions to The Landscape. Smith printed a public thank you.

Being poor himself, Smith identified with the unfortunate. But despite his own poverty, Smith had no sympathy for the labor movement during the social upheaval of the I880s and I890s. He was critical of the strike of trolley car workers in Brooklyn in 1895 .

When we see so much real want and so much unavoidable suffering, borne in silence, we grow indignant at the unnecessary complaining, exaggerated by demagogueism [sic], of which we hear so much....

"Do you sympathize with the Brooklyn strikers?" we are asked. Do we sympathize with Jesse James? ...

If we have any sympathy, we better give it to the tens of thousands all over the country who seek in vain for work, or to those men in Brooklyn, who, with a heroism worthy of song and story, braved death itself to earn something to save their wives and children from starvation. ${ }^{33}$

Smith spoke out forcefully against both anarchism and socialism: "Anarchist and Socialist, professing to be different, agree in the main thing: a desire to live by plunder. The anarchist would plunder without law or government; the socialist would control government and plunder with a pretence of legality." ${ }^{34} \mathrm{He}$ called the anarchist, German-immigrant Johann Most "a natural born criminal of a most vicious and malevolent type. As long as he lives he should be kept behind bars."35 He charged that the yellow journalists and the anarchists were in league with each other.

The demagogic papers with their continual howl about "plutocracy," "the rich growing richer," etc. stirring up bitterness and strife, inciting workmen against employer, class against class, are responsible for the magnitude of the Homestead horrors, and are putting life and property at the mercy of a mob all over the country. Herr Pulitzer and Herr Most are working in the same cause. ${ }^{36}$

When Coxie's Army of unemployed men marched on Washington in the spring of 1894 , Smith wrote: " 'Coxie's Army' is a good illus-

\footnotetext{
32 Ibid., May 1890 , p. 2.

34 Ibid., August I894, p. 2.

${ }^{36}$ Ibid., August 1892, p. 2.
}

33 Ibid., February I 895, p. 2.

35 Ibid, November I901, p. I. 
tration of the growing idiocy of the times. ${ }^{37} \mathrm{He}$ elaborated on what he meant:

In the Coxie's gangs the villanous outcry against "plutocrats," "capitalists," etc. so pleasing to the ear of those who envy all in better circumstances than themselves, is bearing its legitimate fruit. The present movement may be checked, but its ideas will long remain, a menace to life and property, and the children of those who aid the evil may yet pay in blood for the folly of their fathers. ${ }^{38}$

Nor did A. P. Smith approve of the Populists. He ridiculed Mrs. Mary Lease, the Populist leader who advised the farmers of Kansas to raise less corn and more Hell. "Alliance papers call Mrs. Lease the Amazon of Kansas. School books say that the mouth of the Amazon is 200 miles wide. ${ }^{39}$ In the Presidential election of 1896 , Smith opposed William Jennings Bryan. On the issue of the free coinage of silver, Smith wrote:

The mine owners very kindly want to give us a "cheap, poor people's money." The stuff to make it of these benevolent gentlemen whose "sands of life are nearly run," will see you themselves. You can buy 53 cents worth for \$1.00 . . The mightiest "money power" on the continent, the one that above all has profited most by government favor and the one to which, as far as finance is the cause, we can trace the present hard times, is the silver money power of the West. ${ }^{40}$

Smith supported the imperialist foreign policy of the United States at the end of the Nineteenth Century. He wanted the United States to defend its flag against the Germans on Samoa in 1889.

The latest news in the papers. War. War. WAR.

The Great American Eagle has been insulted.

The Germans in Samoa have fired on and burned the American flag...

P.S. The latest.

The flag was only an old one-so no matter. ${ }^{41}$

He favored the Spanish-American war, but opposed the annexation of Cuba. He wrote: "Blot out forever the power of Spain on the American continent! Give us free Cuba, but keep it out of the United States! In the barbarisms of the South and the 'rotten boroughs' of the West, we have enough such 'states!" "42 Yet he was willing for the United States to assume "the white man's burden" by acquiring

37 Ibid., April I 894, p. 2.

39 Ibid., November 1891, p. 4.

41 Ibid., February 1889, p. 2.
${ }^{38}$ Ibid., May 1894, p. 2.

${ }^{40}$ Ibid., September I 896, p. 2.

42 Ibid., February 1897, P. 2. 
the Philippines by force. "Trouble there may be in holding the Philippines. Trouble there would also be in letting them gotrouble for ourselves, for the Filipinos and for the world. Let us, then, take them and do the best circumstances allow."

A. P. Smith was not only patriotic, he also felt much local pride and loyalty. In I 890, when there was talk about constructing a railroad (which was never built) through the Saddle River Valley, Smith criticized those who downgraded the village of Saddle River. He wrote that "when railroad talk degenerated into mere croaking and depreciating the present real advantages, til it became next to impossible to sell a foot of land at a decent price, we felt it time to protest, and to show that Saddle River (the village) was not the undesirable place it was represented to be." ${ }^{\prime 4}$ But he was critical of what he considered the prejudiced, narrow-minded, and superstitious attitudes of some of the residents in nearby Park Ridge, New Jersey. In I 889 rumors spread throughout Park Ridge that the home of the local blacksmith was cursed with poltergeist. Knives and forks allegedly jumped up on the table and danced. An iron, matches, and hairpins were said to fly about the house. An almanac supposedly pursued people from room to room, despite efforts to nail it to the floor. And an empty pair of trousers was seen walking down the stairway behind its owner. In reaction Smith wrote:

In the ignorance of a certain class, superstition finds a congenial soil, and the more ignorant the person, the greater the wonders reported. It is customary to speak of the belief in witchcraft as a thing of the remote past, impossible in the light of the nineteenth century, but that light has not yet penetrated the minds of a class in some portions of Bergen County. ${ }^{45}$

In the I890s, A. P. Smith became the champion of a small band of religious enthusiasts, who established a religious commune on a farm in Woodcliff, New Jersey. The farm was owned by Herman Storms, but his wife, son, and daughter became followers of an itinerant evangelist named Mnason T. Huntsman. Mnason, as he called himself, and his disciples moved on to the Storms farm and renamed it "The Lord's Farm." His followers adopted the names of early Christian martyrs, such as "Titus," "Blandina," and "Phoebe." They refused to eat meat or any animal products; nor did they consume any tea, coffee, or tobacco. Like the Shakers in New York State, they maintained complete chastity and took in orphans

43 Ibid., February I899, p. 2.

${ }^{45}$ Ibid., November 1889 , p. 2.

${ }^{44}$ Ibid., March I89o, p. 3. 
and anyone else who wanted to stay. They were industrious. Not only did they work the Lord's Farm, but they used the farm wagon for a furniture moving business and hired themselves out to neighboring farmers. However, they did not observe the Sabbath, because they believed that every day was holy. The men wore long hair and beards.

Rumors began to spread in nearby Park Ridge. Local residents began to call the religious band the "Angel Dancers," and the people on the Lord's Farm were said to dance naked on the tables. It was rumored that Mnason was worshipped as being Christ incarnate. A. P. Smith lived only a mile from the Lord's Farm, and he visited the farm on several occasions, once staying for an entire week. Smith tried to refute the rumors, which were picked up by the local newspapers.

Some of the papers have again had one of their eruptions concerning the people they name "Angel Dancers." The editor of The Landscape, being personally acquainted with all of those thus called, knows what he is talking about when he has anything to say about "Angel Dancers." We have seen them at their own fireside and elsewhere, and all we have seen has won from us the highest admiration and respect. ${ }^{46}$

The local and county authorities began to persecute the Lord's Farm people. In 1892 several residents of the Lord's Farm were arrested for violating the blue laws by working on Sundays. They were convicted and fined. In the spring of I 893 the entire band was arrested and charged with conspiring to defraud Herman Storms out of his farm. They spent the entire summer in the county jail in Hackensack, waiting for the Grand Jury to convene. In the fall, when it was found that the original charges could not be supported, the charges were changed to keeping a disorderly house. They were tried and convicted. Mnason and one of his followers were sentenced to one year in the state prison. A. P. Smith wrote of the 1893 trial:

The case will furnish a curious chapter in the history of intolerance, and the ignorant and mendacious jumble of a charge on which these people were committed, if preserved, will be read by future generations with wonder at the ignorance, bigotry, and perversion of law, to gratify religious rivalry and spite, in Park Ridge in $1893 .{ }^{47}$

After Mnason was released from prison, he returned to the Lord's Farm. But in 1899 the residents of the Lord's Farm were arrested

${ }^{46}$ Quoted in the Bergen Index (Hackensack, N.J.), April 4, 1895, p. 3.

${ }^{47}$ Ibid., September 23, I 893, p. I. 
again. This time they were charged with assault on two teenage girls and keeping a disorderly house. A woman from Massachusetts, named Mrs. Annie Lamb, with the connivance of a reporter from the sensation-seeking New York World, accused the Lord's Farm people of convincing Mrs. Lamb's daughters to leave home and to hate their parents. After a sensational trial, covered by the New York City newspapers, it was shown that Mrs. Lamb herself had brought the girls to the Lord's Farm. The verdict was not guilty. A. P. Smith attacked the yellow journalism of the New York City newspapers: "People are recognizing the worth of the so-called 'Angel Dancers' concerning whom 'fake' newspapers and filthy imaginations have woven so many romances, which many at one time were credulous enough to believe." ${ }^{\sharp 8} \mathrm{He}$ bragged that his little "country newspaper" was far superior to the big city papers.

The city papers show very plainly their opinion of the intelligence and taste of their readers. A look at their pages makes us think of blackboard exercises for young Digger Indians or a country poster advertising stray cattle. But the great triumph is 'our colored supplement.' How 'Sitting Bull' and his braves would enjoy it! ${ }^{49}$

During the last years of his life, A. P. Smith's health worsened, and he became a shut-in. Nevertheless, he continued to publish The Landscape through July, I90I. On November 27, I901, A. P. Smith died of a cerebral hemorrhage. An inventory of his possessions made a few months after his death showed that his personal property was worth only $\$ 35.10$, of which his most valuable possession was his printing press and type valued at twenty-five dollars. ${ }^{50}$ An obituary in the Hackensack Republican summed up the life of A. P. Smith: "Under more favorable conditions, with health and opportunity to work out the visions that filled his fitfull dream of life, there was reason to believe that Alfred P. Smith, physical wreck, would have been a conspicuous figure and a power among the men of his race." ${ }^{51}$

${ }^{48}$ The Landscape (Saddle River, N.J.), January 1895, p. 2.

49 Ibid., March 1898, p. 2.

${ }^{50}$ Bergen County, New Jersey, Records of Inventories (on file in the Probate Office, Bergen County Courthouse, Hackensack, N.J.), Liber V, pp. 505-6.

${ }^{51}$ Hackensack Republican (Hackensack, N.J.), December 5, I901, p. I. 